\title{
DETERMINATION OF ARTIFICIAL SWEETENERS IN BEVERAGES AND SPECIAL NUTRITIONAL PRODUCTS USING HIGH PERFORMANCE LIQUID CHROMATOGRAPHY
}

\author{
Maja SERDAR ${ }^{1}$ and Zorka KNEŽEVIĆ ${ }^{2}$ \\ Environmental Health Service, Croatian National Institute of Public Health ${ }^{1}$, Croatian Veterinary Institute ${ }^{2}$, \\ Zagreb, Croatia \\ Received in November 2010 \\ Last CrossChecked in May 2011 \\ Accepted in May 2011
}

\begin{abstract}
This paper presents two high performance liquid chromatographic (HPLC) methods used for the separation and determination of artificial sweeteners aspartame, acesulphame $\mathrm{K}$, sodium saccharin, and sodium cyclamate in beverages and special nutritional products (special food intended for specific population groups). All four compounds are soluble in aqueous solutions and can easily be separated and determined by HPLC with a diode array detector (DAD). The first method involved separation of aspartame, acesulphame $\mathrm{K}$, and sodium saccharin on $\mathrm{C}_{18}$ column with an isocratic elution of phosphate buffer and acetonitrile as mobile phase. The second method was used to separate sodium cyclamate on a $\mathrm{C}_{18}$ column with methanol and water as mobile phase. Under optimum conditions, both methods showed good analytical performance, such as linearity, precision, and recovery. The methods were successfully applied for the analysis of real samples of soft drinks and special nutritional products.
\end{abstract}

KEY WORDS: acesulphame $K$, aspartame, sodium cyclamate, sodium saccharin, validation

Artificial sweeteners are common in food, drinks, and pharmaceutical products (1). They are often used to control calorie intake and in certain medical conditions such as diabetes and hyperglycaemia (2). The most common are aspartame, sodium cyclamate, acesulphame $\mathrm{K}$, and sodium saccharin, which are marketed in about 90 countries of the world (3). Aspartame (N-L- $\alpha$-aspartyl-L-phenylalanine-methyl ester) contains two amino acids, aspartic and phenylalanine, and is between 160 and 220 times sweeter than sugar $(4,5)$. Sodium and calcium cyclamates are 30 to 40 times as sweet as sucrose (6). In combination with other low-calorie sweeteners, they are sweeter than the sum of individual sweeteners (7). Acesulphame $\mathrm{K}$ is a strong non-caloric sweetener which does not metabolise in the body, and is excreted unchanged (5). Sodium saccharin has the longest history of use, and has provoked strong controversy over its possible carcinogenic effects (3). The EU and Croatian regulations have established maximum permitted concentrations of artificial sweeteners in food (8-12). Their content in food, drinks, and dietary products is being determined using a variety of methods such as UV spectroscopy $(1,5)$, capillary electrophoresis $(1,4,6)$, high performance liquid chromatography $(1,2,5,7)$, and ion chromatography $(1,3)$.

The aim of this study was to develop and test two methods for routine laboratory analysis of aspartame, sodium cyclamate, acesulphame $\mathrm{K}$, and sodium 
saccharin in soft drinks and special nutritional products.

\section{MATERIAL AND METHODS}

\section{Chemicals}

Reference compounds (acesulphame K, sodium cyclamate, and sodium saccharin) were purchased from Sigma-Aldrich (Steinheim, Germany), and aspartame from Fluka (Buchs, Switzerland). All solid standards were of $\geq 98 \%$ purity. HPLC-grade methanol and acetonitrile were obtained from Merck (Darmstadt, Germany). Water was purified using a Milli-Q Ultrapure water purification system (Millipore, Bedford, MA, USA). Potassium dihydrogen phosphate, phosphoric acid, sulphuric acid, heptane, sodium hypoclorite, sodium carbonate, and sodium sulphate were obtained from Kemika (Zagreb, Croatia).

Stock solutions were prepared separately by dissolving reference compounds in deionised water. Working standard solutions of aspartame, acesulphame $\mathrm{K}$, and sodium saccharin were prepared by mixing and diluting aliquots of stock solutions. Sodium cyclamate in $30 \mathrm{~mL}$ stock solution was derivatised into cyclohexylsulphamic acid because of its poor absorbance.

\section{Samples}

For the analysis, we collected 104 products marketed in Croatia. Seventy-eight were soft drinks (41 from plant extracts, 11 fruit juice samples, and 26 artificially and flavoured drinks) and 26 were special nutritional products, such as baby food, gluten-free

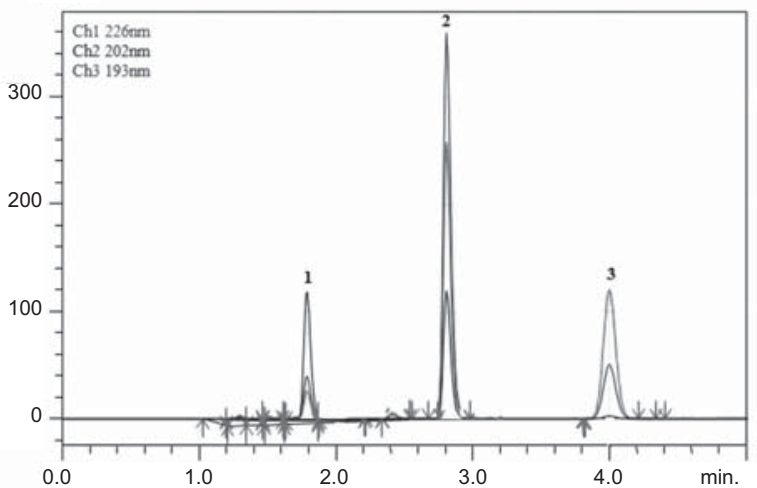

Figure 1 Chromatograms of a standard mixture of artificial sweeteners: 1 -acesulphame K, 2 - sodium saccharin, 3 - aspartame food, food for specific medical purposes, food intended for people suffering of diabetes, food with a reduced or increased energy value, and nutritional supplements (15 in water soluble tablets, and 11 in powders).

\section{Sample preparation}

Samples of soft drinks were degassed for 10 minutes in an ultrasonic bath before dilution with water. To determine aspartame, acesulphame $\mathrm{K}$, and sodium saccharin in soft drinks, we diluted $10-\mathrm{mL}$ samples with deionised water in $100 \mathrm{~mL}$ volumetric flasks. Samples of special nutritional products were weighted to $5 \mathrm{~g}$, placed into $100 \mathrm{~mL}$ glass flasks, diluted to $100 \mathrm{~mL}$ with deionised water, and degassed. Soft drinks and special nutritional product solutions were then filtered into vials through a $0.45 \mu \mathrm{m}$ membrane filter (Whatman, UK) and injected into the HPLC system (13).

To determine sodium cyclamate, $30 \mathrm{~mL}$ stock solutions were derivatised into cyclohexylsulphamic acid, as follows: the liquid sample, $1 \mathrm{~mL}$ of sulphuric acid, $10 \mathrm{~mL}$ of heptanes, and $2.5 \mathrm{~mL}$ of sodium hypoclorite solution were added into a separating funnel. After separating the phases, the aqueous phase was discarded and heptane layer washed with $25 \mathrm{~mL}$ of sodium carbonate solution $\left(50 \mathrm{~g} \mathrm{~L}^{-1}\right)$. The lower phase was discarded and heptane phase dried with $1 \mathrm{~g}$ of sodium sulphate and filtered through a fluted filter paper and then through $0.45 \mu \mathrm{m}$ membrane filter into vials (14).

\section{HPLC conditions}

For chromatography we used Shimadzu LC Prominence 20 HPLC (Kyoto city, Japan) with a diode

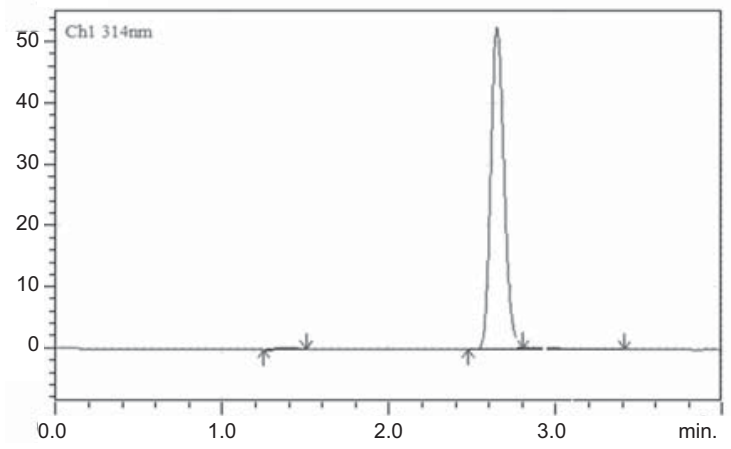

Figure 2 Characteristic chromatogram of cyclohexylsulphamic acid 
Table 1 Analytical performance of the methods used for determination of artificial sweeteners

\begin{tabular}{|c|c|c|c|c|c|}
\hline & \multicolumn{4}{|c|}{ Name of artificial sweetener } \\
\hline & & Acesulfame K & Aspartame & Sodium saccharin & Sodium cyclamate \\
\hline \multicolumn{2}{|l|}{$\Lambda_{\max } / \mathbf{n m}$} & 226 & 193 & 202 & 314 \\
\hline \multicolumn{2}{|c|}{ Linearity range / $\mathrm{mg} \mathrm{L}^{-1}$} & 0.3 to 24.3 & 0.5 to 40.5 & 0.4 to 32.4 & 0.5 to 40.5 \\
\hline \multicolumn{2}{|c|}{ Correlation coefficient / $\mathbf{r}^{2}$} & 1 & 1 & 1 & 0.9999 \\
\hline \multicolumn{2}{|c|}{ Linear equation } & $y=2128 x+6696$ & $y=6425 x-291.9$ & $y=4351 x+7243$ & $y=2334.5 x-7599$ \\
\hline \multicolumn{2}{|c|}{$\mathrm{LOQ} / \mathrm{mg} \mathrm{L}^{-1}$} & 0.3 & 0.5 & 0.4 & 0.5 \\
\hline \multirow{2}{*}{$\begin{array}{l}\text { Precision / } \\
\text { RSD, \% }\end{array}$} & $\begin{array}{l}\text { Injection } \\
\text { repeatability }\end{array}$ & 0.15 & 0.15 & 0.15 & 0.3 \\
\hline & $\begin{array}{l}\text { Analytical } \\
\text { repeatability }\end{array}$ & 0.5 & 0.7 & 0.5 & 0.9 \\
\hline \multirow{2}{*}{ Recovery / \% } & $2 \times \mathrm{LOQ}$ & 101 & 97.5 & 99 & 101 \\
\hline & $10 \times$ LOQ & 98.4 & 96.2 & 100.6 & 99.5 \\
\hline
\end{tabular}

Table 2 Concentration ranges of artificial sweeteners in samples of soft drinks and special nutritional products

\begin{tabular}{|c|c|c|c|c|c|c|}
\hline \multirow[b]{3}{*}{ Analyte } & \multicolumn{5}{|c|}{ Concentration range / $\mathrm{mg} \mathrm{L}^{-1}$} & \multirow{3}{*}{$\begin{array}{c}\text { Maximum } \\
\text { permitted level } \\
\text { / } \mathrm{mg} \mathrm{L}^{-1}\end{array}$} \\
\hline & \multicolumn{3}{|c|}{ Soft drinks } & \multicolumn{2}{|c|}{ Special nutritional products } & \\
\hline & $\begin{array}{c}\text { Soft drinks } \\
\text { from plant } \\
\text { extracts }\end{array}$ & $\begin{array}{l}\text { Fruit } \\
\text { juices }\end{array}$ & $\begin{array}{c}\text { Artificially } \\
\text { and flavored } \\
\text { drinks }\end{array}$ & $\begin{array}{l}\text { Soluble } \\
\text { tablets }\end{array}$ & Powders & \\
\hline \multirow{2}{*}{ Acesulphame K } & 116.75 to & 90.45 to & 206.25 to & 102.07 to & 114.20 to & \multirow{2}{*}{350} \\
\hline & 399.13 & 420.60 & 451.47 & 269.64 & 304.85 & \\
\hline \multirow{2}{*}{ Aspartame } & 153.69 to & 80.29 to & 198.22 to & 143.97 to & 156.97 to & \multirow{2}{*}{600} \\
\hline & 876.42 & 435.05 & 709.36 & 338.75 & 554.35 & \\
\hline \multirow{2}{*}{ Sodium saccharin } & 35.11 to & 40.01 to & 65.77 to & 21.67 to & 39.86 to & \multirow{2}{*}{80} \\
\hline & 134.59 & 55.24 & 76.91 & 66.59 & 75.14 & \\
\hline \multirow{2}{*}{ Sodium cyclamate } & 80.13 to & 70.10 to & 203.68 to & 42.36 to & 87.72 to & \multirow{2}{*}{400} \\
\hline & 627.38 & 583.94 & 621.75 & 240.90 & 315.66 & \\
\hline
\end{tabular}

array detector, and a $\mathrm{C}_{18}$ column $(15 \mathrm{~cm} \times 4.6 \mathrm{~mm}$, $5 \mu \mathrm{m}$ ) manufactured from Supelco (Texas city, USA).

The isocratic elute used for the separation of aspartame, acesulphame $\mathrm{K}$, and sodium saccharin contained $15 \%$ acetonitrile, and $75 \%$ phosphate buffer $\left(0.0125 \mathrm{~mol} \mathrm{~L}^{-1} \mathrm{KH}_{2} \mathrm{PO}_{4}\right.$ at $\left.\mathrm{pH} 3.5\right)$. Elution flow rate was $1.5 \mathrm{~mL} \mathrm{~min}^{-1}$. Total running time was five minutes with injection volume of $10 \mu \mathrm{L}$. Cyclohexylsulphamic acid was separated using isocratic elute consisting of $85 \%$ methanol and $15 \%$ water. The injection volume was $10 \mu \mathrm{L}$ and chromatograms were recorded for four minutes.

Standards were analysed on a separate chromatogram and quantification was based on a comparison between the peak areas of the sample and of the reference standard. The presence of an analyte in the sample was confirmed by a diode array detector. Peaks were confirmed by comparing their spectra with those of the aqueous solutions of the standards.

\section{RESULTS}

The described analytical methods effectively separated the artificial sweeteners of all analysed products. Figures 1 and 2 show the chromatograms of standard solutions.

Method validation data are shown in Table 1. Limits of quantifications (LOQs) were estimated with concentrations giving a signal-to-noise ratio of about 10. LOQ is defined as the lowest concentration on the calibration curve.

Linearity measurement was based on five concentration points with three replicates of standard solution for each concentration level.

The precision of our two methods was evaluated as injection repeatability and analytical repeatability based on five replicates of standard solutions. Precision is expressed as the relative standard deviation (RSD) of the replicates. 
Recovery was determined by spiking selected samples of each matrix with standards at concentrations twice the LOQ and 10 times the LOQ.

\section{Application with real samples}

Artificial sweeteners were found in all analysed products. All products truthfully declared to have "artificial sweeteners" or "no added sugars" on their labels. Table 2 shows concentration ranges and relative maximum levels for each analyte set by Croatian law (13). Twenty-five soft drink samples exceeded the maximum levels, as follows: seven made of plant extracts, two fruit juices, and sixteen artificially flavoured drinks. None of the samples of special nutritional products exceeded maximum limits.

\section{CONCLUSION}

We have found the two described methods suitable for routine analysis of artificial sweeteners in beverages and special nutritional products. Limits of quantification, precision, and recovery were satisfactory.

\section{REFERENCES}

1. Zygler A, Wasik A, Namiesnik J. Analytical methodologies for determination of artificial sweeteners in foodstuffs. TrAC 2009;28:1082-1102.

2. Chen Q, Mou S, Liu K, Yang Z, Ni Z. Separation and determination of four artificial sweeteners and citric acid by high-performance anion-exchange chromatography. J Chromatogr A 1997;771:135-143.
3. Zhu Y, Guo Y, Ye M. James F.S. Separation and simultaneous determination of four artificial sweeteners in food and beverages by ion chromatography. J Chromatogr A 2005;1085:143-146.

4. Pesek J.J, Matyska M.T. Determination of aspartame by high-performance capillary electrophoresis. J Chromatogr A 1997;781:423-428.

5. Cantarelli M.A, Pellerano R.G, Marchevsky E.J, Camina J.M. Simultaneous determination of aspartame and acesulfame-K by molecular absorption spectrophotometry using multivariate calibration and validation by high performance liquid chromatography. Food Chem 2009;115:1128-1132.

6. Horie M, Ishikawa F, Oishi M, Shindo T, Yasui A, Ito K. Rapid detrmination of cyclamate in foods by solid-phase exstraction and capillary electrophoresis. J Chromatogr A 2007;1154:423-428.

7. Huang Z, Ma J, Chen B, Zhang Y, Yao S. Determination of cyclamate in foods by high performance liquid chromatography-electrospray ionization mass spectrometry. Anal Chim Acta 2006;555:233-237.

8. Directive 94/35/EC of European Parliament and of the Council of 30 June 1994 on sweeteners for use in foodstuffs. OJEC 1994, L237/13.

9. Directive 96/83/EC of European Parliament and of the Council of 19 December 1996 amending Directive 94/35/EC on sweeteners for use in foodstuffs. OJEU 1997, L048, 16.

10. Directive 2003/115/EC of European Parliament and of the Council of 22 December 2003 amending Directive 94/35/EC on sweeteners for use in foodstuffs. OJEU 2004, L024, 65.

11. Directive 2006/52/EC of European Parliament and of the Council of 5 July 2006 amending Directive 95/2/EC on food additives other than colours and sweeteners and Directive94/35/EC on sweeteners for use in foodstuffs . OJEU 2004, L204, 10.

12. Pravilnik o prehrambenim aditivima [Food additives regulations in Croatian] Narodne novine 81/2008.

13. EN 12856:1999-Determination of acesulfame-K, aspartame and saccharin by HPLC method.

14. EN 12857:1999 - Determination of cyclamate by HPLC method. 


\section{Sažetak}

ODREĐIVANJE UMJETNIH SLADILA U OSVJEŽAVAJUĆIM BEZALKOHOLNIM PIĆIMA I POSEBNIM PREHRAMBENIM PROIZVODIMA METODOM TEKUĆINSKE KROMATOGRAFIJE VISOKE DJELOTVORNOSTI

Ovaj rad predstavlja dvije metode za separaciju i određivanje umjetnih sladila aspartama, acesulfama K, natrijeva saharina i natrijeva ciklamata u osvježavajućim bezalkoholnim pićima i posebnim prehrambenim proizvodima tehnikom tekućinske kromatografije visoke djelotvornosti (HPLC). Sva četiri analita topljiva su u vodenim otopinama i lako se mogu razdvojiti i odrediti tekućinskom kromatografijom uz primjenu detektora s nizom dioda (DAD). Prva je metoda kromatografsko razdvajanje aspartama, acesulfama K i natrij saharina na $\mathrm{C}_{18}$ koloni izokratnim ispiranjem fosfatnog pufera i acetonitrila kao mobilne faze. Druga metoda omogućava određivanje natrijeva ciklamata na $\mathrm{C}_{18}$ koloni sa metanolom i vodom kao mobilnom fazom. Pod najpovoljnijim eksperimentalnim uvjetima obadvije metode pokazale su dobre analitičke karakteristike, kao što su linearnost, preciznost i analitički povrat. Navedene su metode primijenjene za analize realnih uzoraka osvježavajućih bezalkoholnih pića i hrane za posebne prehrambene potrebe.

KLJUČNE RIJEČI: acesulfam $K$, aspartam, natrijev ciklamat, natrijev saharin, validacija

\section{CORRESPONDING AUTHOR:}

Maja Serdar

Environmental Health Service

Croatian National Institute of Public Health

Rockefellerova 7, 10000 Zagreb, Croatia

E-mail:maja.serdar@hzjz.hr 